\title{
Association between shift work and obesity in a large sample of Iranian steel industry workers
}

\author{
Najmeh Rabanipour ${ }^{1}$, Hamidreza Roohafza ${ }^{2}$, Awat Feizi ${ }^{1,2}$, Shahnaz Amani Tirani ${ }^{3}$, and \\ Nizal Sarrafzadegan ${ }^{4}$ \\ ${ }^{1}$ Department of Biostatistics and Epidemiology, Student Research Center, Isfahan University of Medical Sciences, \\ Isfahan, Iran \\ ${ }^{2}$ Cardiac Rehabilitation Research Center, Cardiovascular Research Institute, Isfahan University of Medical Sciences, \\ Isfahan, Iran \\ ${ }^{3}$ Khorshid Hospital, Nutrition Department, Isfahan University of Medical Sciences, Isfahan, Iran \\ ${ }^{4}$ Isfahan Cardiovascular Research Center, Cardiovascular Research Institute, Isfahan University of Medical Sciences, \\ Isfahan, Iran
}

[Received in March 2019; Similarity Check in March 2019; Accepted in September 2019]

\begin{abstract}
Obesity is associated with several chronic diseases, and previous research suggests that shift work could be associated with the risk of overweight and obesity, but the results remain inconclusive. Furthermore, only a few studies report related findings for industrial workforce with high job-related stress. The aim of this cross-sectional study was to see if such association exists in a large sample of 3063 industrial workers in a developing country. The sample was selected among 16,000 steel company workers through multistage cluster sampling. We took anthropometric measurements, including body mass index (BMI), waist circumference (WC), and waist-to-hip ratio (WHR). Information about potential confounders was collected with a self-administered questionnaire. The association between shift work and both general and abdominal obesity was established with multinomial and binary logistic regression analysis. The study sample consisted of 1683 $(54.9 \%)$ rotational shift workers and $1380(45.1 \%)$ day workers. Shift work was significantly associated with higher risk of overweight after adjusting for the impacts of potential confounders (OR=1.2;95\% CI:1.04-1.4) but not with abdominal obesity. This study established that shift work was an independent risk factor for overweight in industrial shift workers. Modification of working schedules is recommended, particularly for prolonged, continuous shift work.
\end{abstract}

KEY WORDS: abdominal obesity; BMI; general obesity; waist circumference; waist-to-hip ratio

In recent years, shift work has increased in industrialised nations, accounting for more than $20 \%$ of the entire working population $(1,2)$. In Europe and North America it is estimated to account for $15 \%$ of the workforce (3).

Shift work is associated with several health problems resulting from disturbed circadian rhythm. They include obesity, gastrointestinal disorders, several types of cancer, cardiovascular disease, psychological disorders (e.g., depression, insomnia), diabetes, and work accidents $(4,5)$. Obesity and overweight, in turn, are associated with many chronic diseases, including the cardiovascular disease, cerebrovascular disease, type 2 diabetes mellitus, hypertension, and cerebral infarction $(5,6)$. The World Health Organization (WHO) has estimated that about 1.9 billion of the world population were overweight and over 650 million obese in 2016 (7).

The worldwide prevalence of overweight and obesity combined rose $27.5 \%$ in adults and $47.1 \%$ in children

\footnotetext{
Corresponding author: Awat Feizi, Cardiac Rehabilitation Research Center, Cardiovascular Research Institute and Department of Biostatistics and Epidemiology, Isfahan University of Medical Sciences, Isfahan, Iran E-mail:awatfeiz@hlth.mui.ac.ir
}

between 1980 and 2013. In about the same time, this prevalence increased $49.4 \%$ in men and $63.3 \%$ in women in Iran (8).

Previous studies suggest that obesity and overweight are more prevalent in shift workers than day workers (9, 10) and have established an association between the two (11-13). However, some of them have taken into account only body mass index (BMI) as a measure of general obesity instead of looking at the distribution of fat and distinguishing between overweight due to muscle or fat tissue mass (14). Abdominal fat is known to affect organs like the heart, kidneys, and liver more adversely than fat around the hips and bottom (15).

The association between shift work and obesity in Iranian working population has been investigated poorly, especially in industrial workers at high risk of job-related stress $(16,17)$. The aim of this epidemiological study was therefore to address this gap in knowledge on a large sample of Iranian steel industry workers, taking into account possible confounding factors and distinguishing between general obesity/overweight (BMI) and abdominal adiposity (waist circumference and waist-to-hip ratio). 


\section{PARTICIPANTS AND METHODS}

\section{Study design and sample}

This cross-sectional study was conducted among full employees and contractual workers of the Esfahan Steel Company (workforce of 16,000). The sample size was determined based on an epidemiological survey of chronic diseases in manufacturing employees by Roohafza et al. (ESCOME) (18) carried out to estimate the prevalence of psychological disorders (depression and anxiety) among the workforce. The sample size was estimated to be 3500 by considering $0.1(19,20), 0.05$, and 0.01 as prevalence of psychological disorders, type one error rate, and sampling error rate, respectively.

Three thousand and sixty-three volunteers returned complete questionnaires (response rate: 0.87 ) and were included in statistical analysis. The inclusion criterion was work experience for at least one year and willing and agreeing to participate in the study. Volunteers who did not answer more than $10 \%$ of the questionnaire were excluded from analysis.

We applied multi-stage cluster sampling, in which clusters were the main seven departments and their sections, stratified by job categories. Sample sizes in the clusters and strata were proportional to the size of respective departments. Due to a low number of women workers $(n=800)$, we relied on convenience sampling to recruit women volunteers $(\mathrm{n}=260)$.

Demographic data were gathered through selfadministered questionnaires at the company premises with the help of study coordinators, who also monitored questionnaire administration over the six months of data gathering. The data were quality checked for inclusion and exclusion criteria as they were entered in the computer for statistical analysis. The study design and its implementation has been presented elsewhere in more detail (18).

All participants were informed about the study protocol and signed informed consent. Medical research ethics committee of the Isfahan University of Medical Sciences approved the study protocol (research project No.196222).

\section{Determining participants who worked in shifts}

Participants were considered as shift workers if they answered "yes" to the question "Do you currently work in shifts?" The company rotates its shifts in a fixed pattern: morning shift, followed by an afternoon shift, and then a night shift, which is then repeated.

\section{Assessment of body mass index and abdominal obesity}

Anthropometric indices were measured by trained medical staff according to the World Health Organization (WHO) criteria (21) following standard protocols. At height and weight measurements, the participants wore light clothing and no shoes. Weight was rounded to the nearest
$0.5 \mathrm{~kg}$. Height was measured with a stadiometer and rounded to the nearest $0.1 \mathrm{~cm}$. BMI was calculated as the ratio of weight $(\mathrm{kg})$ to the square of height $\left(\mathrm{m}^{2}\right)$. Waist circumference was measured with a tape midway between the lowest rib and the iliac crest while the participants were standing. Hip circumference was measured at level with the maximum size of the buttocks (22). BMI was categorised according to the classical WHO definition as underweight $\left(<18.5 \mathrm{~kg} / \mathrm{m}^{2}\right)$, normal $\left(18.5-25 \mathrm{~kg} / \mathrm{m}^{2}\right)$, overweight $(25-$ $\left.30 \mathrm{~kg} / \mathrm{m}^{2}\right)$, and obese $\left(\geq 30 \mathrm{~kg} / \mathrm{m}^{2}\right.$. Indices of abdominal obesity were defined as waist circumference (WC) above $88 \mathrm{~cm}$ and a waist-to-hip ratio (WHR) above $87.5 \%$ for men and $83.5 \%$ for women $(23,24)$.

\section{Confounder variables}

Variables that were considered as potential confounders included demographics [age (years), gender (male/female), marital status (married/single), education (0-5 years / 6-12 years / over 12 years)], lifestyle variables [sleep duration (hours) and physical activity (hours per week)], job-related variables [job stress (effort-reward imbalance), and second job (yes/no)]. Physical activity was evaluated with the International Physical Activity Questionnaire (IPAQ), which included 11 questions. The internal reliability of this questionnaire was reported good by Moghaddam et al. (25), based on Cronbach's alpha of 0.7 and Spearman Brown correlation coefficient of 0.9 . Job stress was evaluated with the 23-item Effort-Reward Imbalance (ERI) questionnaire, which is composed of three scales: effort (6 items), reward (11 items), and over-commitment (6 items). Its Cronbach's alpha for effort, reward, and over-commitment subscales is $0.61,0.85$, and 0.67 , respectively (26). We took into consideration the ratio between effort and reward. Participants with the effort/reward ratio of 1.0 or higher were considered to experience ERI or higher job stress (26, 27).

\section{Statistical analysis}

Quantitative and qualitative variables were expressed as means \pm standard deviation (SD) and as frequency (percentage), respectively. Independent-samples $t$-test and chi-square test were used to compare continuous and categorical variables between groups. Multinomial and binary logistic regression were used to identify the association between shift work and either general obesity or abdominal obesity in crude and adjusted models. Multivariate logistic regression models were adjusted for confounding (demographic, lifestyle, and job-related) variables that were statistically significant in univariate analyses. The strength of associations was expressed as odds ratio (OR) and $95 \%$ confidence interval (CI). All statistical analyses were performed with SPSS version 16 (SPSS Inc., Chicago, IL, USA). 


\section{RESULTS}

Table 1 shows the demographics of the study participants by shift work status. Compared to day workers, shift workers were mostly male and significantly younger $(p<0.0001)$ and had lower education and higher sleep duration and job stress. No significant differences were found between the two groups in terms of marital status, physical activity, and second job.

Table 2 shows the prevalence of overweight/obesity and mean obesity indices. No significant differences were found between shift and day workers, but overweight prevailed in shift workers ( $46.2 \%$ vs. $42.1 \%)$.

Table 3 shows the results of multinomial logistic regression analyses. Shift work was significantly associated with the risk of overweight (OR=1.2; $95 \%$ CI:1.04-1.4) after adjusting for confounding variables. However, no significant association was found between shift work and other BMI categories (underweight and obesity). We also observed significant association between overweight and age, sex, and education.

Table 4 shows the results of multivariable binominal logistic regression analyses of associations between shift work and abdominal obesity. Although shift work increased the risk of abdominal obesity, the association was not significant after adjustment for potential confounders.

\section{DISCUSSION}

Our study has demonstrated that overweight is common in industrial working population and that shift work significantly increases its risk, as reported by a number of earlier studies (14, 28-30). The mechanism linking shift work and particularly night shift work with higher BMI has not been fully understood, but Garaulet et al. (31) suggest that the culprit should be sought in the disruption of the circadian rhythm and in sleep deprivation, as they are likely to affect metabolism and the feeling of hunger, which may result in excess energy intake, particularly in the evening. Sleep deprivation decreases leptin and increases ghrelin, which seems to coincide with greater appetite and weight gain (31-33).

In our study abdominal obesity was associated with shift work, but not significantly. Only a few other epidemiological studies have investigated the association between shift work and abdominal obesity and reported inconsistent findings. For instance, in a cross-sectional study of 1324 male workers Karlsson et al. (34) reported no significant association. Esquirol et al. (35) reported similar findings in 98 shift workers (compared to 100 day workers). The absence of significant association was also reported by Sun et al. (36) in a prospective cohort study of $3871 \mathrm{shift}$ workers in China. In contrast, the same group of authors reported the results of a meta-analysis published one year earlier (37), which confirmed the association with abdominal obesity. Bacquer et al. (38) followed 1529 workers from several large Belgian companies and concluded that the risk of abdominal obesity was greater in shift workers than in day workers. Peplonska et al. (39) also found significant association between night shift work and waist circumference in 724 female nurses and midwives However, they found no association with WHR of $>0.85$.

Table 1 Demographics of industrial workers at the Isfahan Steel Company

\begin{tabular}{|c|c|c|c|c|c|}
\hline \multirow[t]{2}{*}{ Characteristics } & \multicolumn{2}{|c|}{$\begin{array}{l}\text { Shift workers } \\
n=1683(54.9)\end{array}$} & \multicolumn{2}{|c|}{$\begin{array}{c}\text { Day workers } \\
n=1380(45.1)\end{array}$} & \multirow[t]{2}{*}{ P-value* } \\
\hline & $\mathbf{N}(\%)$ & Mean (SD) & $\mathbf{N}(\%)$ & Mean (SD) & \\
\hline Age (year) & & $35.98 \pm 6.98$ & & $37.67 \pm 7.59$ & $<0.0001$ \\
\hline Sex & & & & & $<0.0001$ \\
\hline Male & $1618(96.1)$ & & $1185(85.9)$ & & \\
\hline Female & $65(3.9)$ & & $195(14.1)$ & & \\
\hline Marital status & & & & & 0.06 \\
\hline Married & $1531(91)$ & & $1227(88.9)$ & & \\
\hline Single & $152(9)$ & & $153(11.1)$ & & \\
\hline Education years & & & & & $<0.0001$ \\
\hline $0-5$ year & $135(8)$ & & $120(8.7)$ & & \\
\hline 6-12 year & $1213(72.1)$ & & $695(50.4)$ & & \\
\hline$>12$ year & $335(19.9)$ & & $565(40.9)$ & & \\
\hline Sleep duration (hour) & & $7.27 \pm 1.18$ & & $6.92 \pm 1.12$ & $<0.0001$ \\
\hline Physical activity (hours per week) & & $7.31 \pm 3.63$ & & $7.35 \pm 3.68$ & 0.76 \\
\hline Job stress (assessed by ERI) & & $0.64 \pm 0.21$ & & $0.69 \pm 0.24$ & $<0.0001$ \\
\hline Second job & & & & & 0.094 \\
\hline Yes & $170(10.1)$ & & $115(8.3)$ & & \\
\hline
\end{tabular}

ERI - effort-reward imbalance; * independent sample $t$-test and chi-square test 
Table 2 Obesity indices and prevalence of overweight/obesity in total sample and shift and day workers

\begin{tabular}{|c|c|c|c|c|c|c|}
\hline \multirow{2}{*}{ Obesity indices } & \multirow[t]{2}{*}{ Total } & \multicolumn{2}{|c|}{$\begin{array}{c}\text { Shift workers } \\
\quad \mathrm{N}=1683\end{array}$} & \multicolumn{2}{|c|}{$\begin{array}{c}\text { Day workers } \\
\mathrm{N}=1380\end{array}$} & \multirow{2}{*}{ P-value* } \\
\hline & & N (\%) & Mean \pm SD & N (\%) & Mean \pm SD & \\
\hline BMI* $\left(\mathrm{kg} / \mathrm{m}^{2}\right)$ & $25.6 \pm 3.8$ & & $25.52 \pm 3.64$ & & $25.68 \pm 3.97$ & 0.06 \\
\hline Underweight & $67(2.2)$ & $36(2.1)$ & & $31(2.2)$ & & \\
\hline Normal weight & $1288(42.1)$ & 699 (41.6) & & $589(42.7)$ & & \\
\hline Overweight & $1353(44.2)$ & $773(46)$ & & $580(42.1)$ & & \\
\hline Obesity & $353(11.5)$ & $174(10.3)$ & & $179(13)$ & & \\
\hline $\begin{array}{l}\text { Waist circumference } \\
(\mathrm{WC})^{* *}(\mathrm{~cm})\end{array}$ & $88.6 \pm 9.9$ & & $88.77 \pm 9.45$ & & $88.42 \pm 10.41$ & 0.33 \\
\hline $\mathrm{WC} \leq 88 \mathrm{~cm}$ & $1526(49.9)$ & $827(49.2)$ & & $699(50.7)$ & & \\
\hline Abdominal obesity & $1535(50.1)$ & $855(50.8)$ & & $680(49.3)$ & & \\
\hline $\begin{array}{l}\text { Waist to hip ratio } \\
\text { (WHR)**** }\end{array}$ & $88.3 \pm 0.07$ & & $88.5 \pm 0.06$ & & $88.1 \pm 0.07$ & 0.2 \\
\hline For Men & & & $88.7 \pm 0.06$ & & $89.3 \pm 0.06$ & 0.1 \\
\hline $\mathrm{WHR} \leq 87.5 \%$ & $1122(40)$ & $678(41.9)$ & & $460(38.9)$ & & \\
\hline Abdominal obesity & $1680(60)$ & $940(58.1)$ & & $723(61.1)$ & & \\
\hline For Women & & & $81.7 \pm 0.07$ & & $81.3 \pm 0.1$ & 0.94 \\
\hline $\mathrm{WHR} \leq 83.5 \%$ & $179(69.1)$ & $44(68.8)$ & & $135(69.2)$ & & \\
\hline Abdominal obesity & $80(30.9)$ & $20(31.3)$ & & $60(30.8)$ & & \\
\hline
\end{tabular}

BMI - body mass index; WC - waist circumference; WHR - waist-to-hip ratio; ${ }^{*}$ independent $t$-test and chi-square test for continuous and categorical data

Table 3 Association between shift work and BMI adjusted for confounders

\begin{tabular}{|c|c|c|c|c|c|c|c|}
\hline \multirow{2}{*}{ Variables } & \multirow{2}{*}{$\begin{array}{c}\begin{array}{c}\text { Normal } \\
\text { weight }\end{array} \\
\text { (BMI 18.5- } \\
\text { 25, N=1288) } \\
\text { as reference } \\
\begin{array}{c}\text { Adjusted OR } \\
\text { (95\% CI) }\end{array}\end{array}$} & \multicolumn{2}{|c|}{$\begin{array}{l}\text { Underweight }(\mathrm{BMI}<18.5 \text {, } \\
\qquad \mathrm{N}=67)\end{array}$} & \multicolumn{2}{|c|}{$\begin{array}{l}\text { Overweight (BMI 25-30, } \\
\qquad \text { N=1353) }\end{array}$} & \multicolumn{2}{|c|}{$\begin{array}{c}\text { Obesity }(\mathrm{BMI} \geq \mathbf{3 0}, \\
\mathbf{N}=\mathbf{3 5 3})\end{array}$} \\
\hline & & $\begin{array}{c}\text { Adjusted OR } \\
\text { (95\% CI) }\end{array}$ & P-Value & $\begin{array}{c}\text { Adjusted OR } \\
\text { (95\% CI) }\end{array}$ & P-Value & $\begin{array}{c}\text { Adjusted OR } \\
\text { (95\% CI) }\end{array}$ & P-Value \\
\hline $\begin{array}{l}\text { Shift } \\
\text { workers }\end{array}$ & 1 & $0.88(0.5-1.5)$ & 0.6 & $1.2(1.04-1.4)$ & 0.02 & $0.9(0.7-1.2)$ & 0.6 \\
\hline $\begin{array}{l}\text { Day } \\
\text { workers }\end{array}$ & & 1 & & 1 & & 1 & \\
\hline Age (years) & 1 & $0.97(0.9-1.01)$ & 0.1 & $1.06(1.04-1.07)$ & $<0.0001$ & $1.1(1.05-1.09)$ & $<0.0001$ \\
\hline Sex & 1 & & & & & & \\
\hline Male & & $0.59(0.3-1.3)$ & 0.2 & $1.6(1.2-2.1)$ & 0.003 & $1.1(0.7-1.7)$ & 0.6 \\
\hline Female & & 1 & & 1 & & 1 & \\
\hline $\begin{array}{l}\text { Education } \\
\text { years }\end{array}$ & 1 & & & & & & \\
\hline $0-5$ years & & $1.6(0.6-4.7)$ & 0.3 & $0.52(0.4-0.7)$ & $<0.0001$ & $0.6(0.4-1.01)$ & 0.055 \\
\hline $6-12$ years & & $1.3(0.7-2.4)$ & 0.4 & $0.9(0.8-1.1)$ & 0.5 & $1.1(0.8-1.5)$ & 0.45 \\
\hline$>12$ years & & 1 & & 1 & & 1 & \\
\hline $\begin{array}{l}\text { Sleep } \\
\text { duration } \\
\text { (hours) }\end{array}$ & 1 & $1.2(0.99-1.5)$ & 0.07 & $0.95(0.9-1.02)$ & 0.15 & $0.9(0.8-1.02)$ & 0.1 \\
\hline $\begin{array}{l}\text { Job stress } \\
\text { (ERI) }\end{array}$ & 1 & $0.4(0.1-1.4)$ & 0.2 & $1.4(0.9-1.9)$ & 0.1 & $1.4(0.8-2.4)$ & 0.2 \\
\hline
\end{tabular}

BMI - body mass index; ERI - effort-to-reward imbalance 
Table 4 Association between shift work and abdominal obesity adjusted for confounders

\begin{tabular}{|c|c|c|c|c|c|c|}
\hline \multirow{2}{*}{ Characteristics } & \multicolumn{2}{|c|}{$\begin{array}{c}\mathrm{WC}>88 \mathrm{~cm} \\
\mathrm{~N}=1535\end{array}$} & \multicolumn{2}{|c|}{$\begin{array}{c}\text { WHR }>87.5 \% \text { for men } \\
\qquad=1680\end{array}$} & \multicolumn{2}{|c|}{$\begin{array}{c}\text { WHR }>83.5 \% \text { for women } \\
\text { N }=80\end{array}$} \\
\hline & $\begin{array}{c}\text { Adjusted OR } \\
(95 \% \mathrm{CI}) \\
\end{array}$ & P-value & $\begin{array}{l}\text { Adjusted OR } \\
(95 \% \mathrm{CI})\end{array}$ & P-value & $\begin{array}{c}\text { Adjusted OR } \\
(95 \% \mathrm{CI})\end{array}$ & P-value \\
\hline Shift workers & $1.1(0.97-1.3)$ & 0.1 & $1.1(0.9-1.3)$ & 0.2 & $1.005(0.5-1.9)$ & 0.99 \\
\hline Day workers & Ref & & 1 & & 1 & \\
\hline Age (years) & $1.1(1.07-1.09)$ & $<0.0001$ & $1.1(1.1-1.13)$ & $<0.0001$ & $1.06(1.02-1.1)$ & 0.004 \\
\hline \multicolumn{7}{|l|}{ Sex } \\
\hline Male & $3.9(2.9-5.4)$ & $<0.0001$ & & & & \\
\hline Female & Ref & & & & & \\
\hline Education years & & 0.001 & & 0.2 & & 0.95 \\
\hline $0-5$ years & $0.55(0.4-0.7)$ & $<0.0001$ & $0.7(0.5-1.04)$ & 0.1 & $\begin{array}{c}\text { Not } \\
\text { computable }\end{array}$ & \\
\hline $6-12$ years & $0.9(0.7-1.05)$ & 0.2 & $0.95(0.8-1.15)$ & 0.6 & $1.1(0.6-2.04)$ & 0.75 \\
\hline$>12$ years & Ref & & 1 & & 1 & \\
\hline $\begin{array}{l}\text { Sleep duration } \\
\text { (hours) }\end{array}$ & $0.96(0.9-1.03)$ & 0.3 & $0.997(0.9-1.1)$ & 0.9 & $1.05(0.8-1.3)$ & 0.7 \\
\hline Job stress (ERI) & $1.4(1.01-2)$ & 0.04 & $1.3(0.9-1.9)$ & 0.2 & $1.003(0.3-3.4)$ & 0.996 \\
\hline
\end{tabular}

WC - waist circumference; WHR - waist to hip ratio

Like many cross-sectional studies, our study has the inherent limitation that it cannot evidence causal relationship from the obtained significant associations. This could be overcome by a future longitudinal study that could provide higher level of evidence. Another limitation is that we did not compare different shift work schedules (permanent shift, rotating shift, irregular shift), as we assumed only the rotational one, nor did we take into account the years of work (in general or for shift work alone) or potential differences in dietary habits between shift and day workers.

Even with these limitations our study has its merits. The first is the large sample of Iranian industrial workers that includes a large fraction of shift workers. It is also the first comprehensive study in Iran investigating the association between shift work and general and abdominal obesity, and as such, it complements the findings for industrial workers all over the world. Furthermore, our analysis took into account many potential cofounding variables. In conclusion, it has shown that shift work is associated with the risk of overweight, but failed to show the same association with abdominal obesity. In practical terms, our findings call for optimising shift work schedules and implementing occupational health education programmes to reduce obesity-related health risks.

\section{Acknowledgement}

This study was funded in part by the Cardiovascular Research Institute of Isfahan, Iran. We are grateful to all volunteers who participated. We would also like to acknowledge the help of the head of Esfahan Steel Company and the staff of the Cardiovascular Research Institute in conducting the study.

\section{Conflict of interests}

None to declare.

\section{REFERENCES}

1. Pietroiusti A, Forlini A, Magrini A, Galante A, Coppeta L, Gemma G, Romeo E, Bergamaschi A. Shift work increases the frequency of duodenal ulcer in $H$ pylori infected workers. Occup Environ Med 2006;63:773-5. doi: 10.1136/ oem.2006.027367

2. Haus E, Smolensky M. Biological clocks and shift work: circadian dysregulation and potential long-term effects. Cancer Causes Control 2006;17:489-500. doi: 10.1007/ s10552-005-9015-4

3. Straif K, Baan R, Grosse Y, Secretan B, El Ghissassi F, Bouvard V, Altieri A, Benbrahim-Tallaa L, Cogliano V; WHO International Agency For Research on Cancer Monograph Working Group. Carcinogenicity of shift-work, painting, and fire-fighting. Lancet Oncol 2007;8:1065-6. doi: 10.1016/ S1470-2045(07)70373-X

4. Wang XS, Armstrong MEG, Cairns BJ, Key TJ, Travis RC. Shift work and chronic disease: the epidemiological evidence. Occup Med (Lond) 2011;61:78-89. doi: 10.1093/occmed/ kqr001

5. Hermansson J, Hallqvist J, Karlsson B, Knutsson A, Gillander Gådin K. Shift work, parental cardiovascular disease and myocardial infarction in males. Occup Med (Lond) 2018;68:120-5. doi: 10.1093/occmed/kqy008

6. Williams EP, Mesidor M, Winters K, Dubbert PM, Wyatt SB. Overweight and obesity: prevalence, consequences, and causes of a growing public health problem. Curr Obes Rep 2015;4:363-70. doi: 10.1007/s13679-015-0169-4

7. World Health Organization (WHO). Obesity and overweight [displayed 9 May 2018]. Available at http://www.who.int/ en/news-room/fact-sheets/detail/obesity-and-overweight 
8. Ng M, Fleming T, Robinson M, Thomson B, Graetz N, Margono C, Mullany EC, Biryukov S, Abbafati C, Abera SF, Abraham JP, Abu-Rmeileh NM, Achoki T, AlBuhairan FS, Alemu ZA, Alfonso R, Ali MK, Ali R, Guzman NA, Ammar W, Anwari P, Banerjee A, Barquera S, Basu S, Bennett DA, Bhutta Z, Blore J, Cabral N, Nonato IC, Chang JC, Chowdhury R, Courville KJ, Criqui MH, Cundiff DK, Dabhadkar KC, Dandona L, Davis A, Dayama A, Dharmaratne SD, Ding EL, Durrani AM, Esteghamati A, Farzadfar F, Fay DF, Feigin VL, Flaxman A, Forouzanfar MH, Goto A, Green MA, Gupta R, Hafezi-Nejad N, Hankey GJ, Harewood HC, Havmoeller R, Hay S, Hernandez L, Husseini A, Idrisov BT, Ikeda N, Islami F, Jahangir E, Jassal SK, Jee SH, Jeffreys M, Jonas JB, Kabagambe EK, Khalifa SE, Kengne AP, Khader YS, Khang YH, Kim D, Kimokoti RW, Kinge JM, Kokubo Y, Kosen S, Kwan G, Lai T, Leinsalu M, Li Y, Liang X, Liu S, Logroscino G, Lotufo PA, Lu Y, Ma J, Mainoo NK, Mensah GA, Merriman TR, Mokdad AH, Moschandreas J, Naghavi M, Naheed A, Nand D, Narayan KM, Nelson EL, Neuhouser ML, Nisar MI, Ohkubo T, Oti SO, Pedroza A, Prabhakaran D, Roy N, Sampson U, Seo H, Sepanlou SG, Shibuya K, Shiri R, Shiue I, Singh GM, Singh JA, Skirbekk V, Stapelberg NJ, Sturua L, Sykes BL, Tobias M, Tran BX, Trasande L, Toyoshima H, van de Vijver S, Vasankari TJ, Veerman JL, Velasquez-Melendez G, Vlassov VV, Vollset SE, Vos T, Wang C, Wang X, Weiderpass E, Werdecker A, Wright JL, Yang YC, Yatsuya H, Yoon J, Yoon SJ, Zhao Y, Zhou M, Zhu S, Lopez AD, Murray CJ, Gakidou E. Global, regional, and national prevalence of overweight and obesity in children and adults during 1980-2013: a systematic analysis for the Global Burden of Disease Study 2013. Lancet 2014;384:76681. doi: 10.1016/S0140-6736(14)60460-8

9. Son M, Ye BJ, Kim J-I, Kang S, Jung K-Y. Association between shift work and obesity according to body fat percentage in Korean wage workers: data from the fourth and the fifth Korea National Health and Nutrition Examination Survey (KNHANES 2008-2011). Ann Occup Environ Med 2015;27:32. doi: 10.1186/s40557-015-0082-Z

10. Liu Q, Shi J, Duan P, Liu B, Li T, Wang C, Li H, Yang T, Gan Y, Wang X, Cao S, Lu Z. Is shift work associated with a higher risk of overweight or obesity? A systematic review of observational studies with meta-analysis. Int J Epidemiol 2018;47:1956-71. doi: 10.1093/ije/dyy079

11. Macagnan J, Pattussi MP, Canuto R, Henn RL, Fassa AG, Olinto MTA. Impact of nightshift work on overweight and abdominal obesity among workers of a poultry processing plant in southern Brazil. Chronobiol Int 2012;29:336-43. doi: 10.3109/07420528.2011.653851

12. van Drongelen A, Boot C, Merkus S, Smid T, Beek AJ. The effects of shift work on body weight change - a systematic review of longitudinal studies. Scand J Work Environ Health 2011;37:263-75. doi: 10.5271/sjweh.3143

13. Barbadoro P, Santarelli L, Croce N, Bracci M, Vincitorio D, Prospero E, Minelli A. Rotating shift-work as an independent risk factor for overweight Italian workers: a cross-sectional study. PLoS One 2013;8(5):e63289. doi: 10.1371/journal. pone. 0063289

14. Nuttall FQ. Body mass index: obesity, BMI, and health: a critical review. Nutr Today 2015;50:117-28. doi: 10.1097/ NT.0000000000000092

15. Gopinath S, Ganesh BA, Manoj K, Rubiya. Comparision between body mass index and abdominal obesity for the screening for diabetes in healthy individuals. Indian $\mathrm{J}$ Endocrinol Metab 2012;16(Suppl 2):S441-2. doi: $10.4103 / 2230-8210.104124$

16. Gholami Fesharaki M, Kazemnejad A, Zayeri F, Rowzati M, Akbari H. Relationship between shift work and obesity; A retrospective cohort study. Iran J Mil Med 2012;14:93-7.

17. Zayeri F, Khadem Maboudi AA, Hassanzadeh H, Kahaki AN, Salari M. [Assessment of the relationship between shift work and body mass index in petrochemical staff using latent growth curve model, in Persian]. Daneshvar Med 2015;22(117):74-84.

18. Roohafza H, Feizi A, Amani Tirani S, Rabiei K, Alikhasi ABH, Sarrafzadegan N. Epidemiological survey of chronic diseases on manufacturing employees (ESCOME): Design and methodology of a large cross-sectional study. Clin Epidemiol Glob Health [in press]. doi: 10.1016/j. cegh.2019.08.012

19. Andrea H, Bültmann U, Beurskens A, Swaen GMH, Van Schayck CP, Kant IJ. Anxiety and depression in the working population using the HAD Scale. Soc Psychiatry Psychiatr Epidemiol 2004;39:637-46. doi: 10.1007/s00127-004-0797-6

20. Sadeghirad B, Haghdoost A-A, Amin-Esmaeili M, Ananloo ES, Ghaeli P, Rahimi-Movaghar A, Talebian E, Pourkhandani A, Noorbala AA, Barooti E. Epidemiology of major depressive disorder in Iran: a systematic review and metaanalysis. Int J Prev Med 2010;1:81-91. PMCID: PMC3075476

21. World Health Organization (WHO). Physical Status: the Use and Interpretation of Anthropometry. WHO Technical Report Series 854. Geneva: WHO; 1995.

22. Caballero B. The global epidemic of obesity: an overview. Epidemiol Rev 2007;29:1-5. doi: 10.1093/epirev/mxm012

23. Woo J, Ho SC, Yu ALM, Sham A. Is waist circumference a useful measure in predicting health outcomes in the elderly? Int J Obes Relat Metab Disord 2002;26:1349-55. doi: 10.1038/sj.ijo.0802080

24. Jahanlou AS, Kouzekanani K. The development of appropriate waist-to-hip ratio cut-off points: survey in large Iranian adult population. Avicenna J Clin Med 2015;22:144-51.

25. Moghaddam MHB, Aghdam FB, Jafarabadi MA, Allahverdipour H, Nikookheslat SD, Safarpour S. The Iranian version of International Physical Activity Questionnaire (IPAQ) in Iran: content and construct validity, factor structure, internal consistency and stability. World Appl Sci 2012;18:1073-80. doi: 10.5829/idosi.wasj.2012.18.08.754

26. Yadegarfar GH, Alinia T, Hassannezhad R, Fayaz M, Hosseini R, Sanati J, Harandi J, Haj Noroozali V, Baghi Mh, Mirzavand E, Harandi A. [Validation and localization of Farsi version of effort-reward imbalance questionnaire to measure job stress among employees of Isfahan Polyacryle Corporation, in Persian]. Iran J Epidemiol 2012;8:73-83.

27. Siegrist J, Li J, Montano D. Psychometric properties of the effort-reward imbalance questionnaire. University Düsseldorf 2014 [displayed 5 September 2019]. Available at https:// www.uniklinik-duesseldorf.de/patienten-besucher/ klinikeninstitutezentren/institut-fuer-medizinischesoziologie/forschung/the-eri-model-stress-and-health/eriquestionnaires/questionnaires-download

28. Suwazono Y, Dochi M, Sakata K, Okubo Y, Oishi M, Tanaka K, Kobayashi E, Kido T, Nogawa K. A longitudinal study on the effect of shift work on weight gain in male Japanese workers. Obesity (Silver Spring) 2008;16:1887-93. doi: 10.1038/oby.2008.298 
29. Zhao I, Bogossian F, Turner C. A cross-sectional analysis of the association between night-only or rotating shift work and overweight/obesity among female nurses and midwives. J Occup Environ Med 2012;54:834-40. doi: 10.1097/ JOM.0b013e31824e1058

30. Kubo T, Oyama I, Nakamura T, Shirane K, Otsuka H, Kunimoto M, Kadowaki K, Maruyama T, Otomo H, Fujino Y, Matsumoto T, Matsuda S. Retrospective cohort study of the risk of obesity among shift workers: findings from the Industry-based Shift Workers' Health study, Japan. Occup Environ Med 2011;68:327-31. doi: 10.1136/oem.2009.054445

31. Garaulet M, Ordovás JM, Madrid JA. The chronobiology, etiology and pathophysiology of obesity. Int J Obes (Lond) 2010;34:1667-83. doi: 10.1038/ijo.2010.118

32. Taheri S, Lin L, Austin D, Young T, Mignot E. Short sleep duration is associated with reduced leptin, elevated ghrelin, and increased body mass index. PLoS Med 2004;1(3):e62. doi: 10.1371/journal.pmed.0010062

33. Spiegel K, Tasali E, Penev P, Van Cauter E. Brief communication: sleep curtailment in healthy young men is associated with decreased leptin levels, elevated ghrelin levels, and increased hunger and appetite. Ann Intern Med 2004;141:846-50. doi: 10.7326/0003-4819-141-11200412070-00008

34. Karlsson BH, Knutsson AK, Lindahl BO, Alfredsson LS. Metabolic disturbances in male workers with rotating threeshift work. Result of the WOLF study. Int Arch Occup
Environ Health 2003;76:424-30. doi: 10.1007/s00420-0030440-y

35. Esquirol Y, Bongard V, Mabile L, Jonnier B, Soulat JM, Perret B. Shift work and metabolic syndrome: Respective impacts of job strain, physical activity, and dietary rhythms. Chronobiol Int 2009;26:544-59. doi: 10.1080/07420520902821176

36. Sun M, Feng W, Wang F, Zhang L, Wu Z, Li Z, Zhang B, He Y, Xie S, Li M, Fok JPC, Tse G, Wong MCS, Tang JL, Wong SYS, Vlaanderen J, Evans G, Vermeulen R, Tse LA. Night shift work exposure profile and obesity : Baseline results from a Chinese night shift worker cohort. PLoS One 2018;13(5):e0196989. doi: 10.1371/journal.pone.0196989

37. Sun M, Feng W, Wang F, Li P, Li Z, Li M, Tse G, Vlaanderen J, Vermeulen R, Tse LA. Meta-analysis on shift work and risks of specific obesity types. Obes Rev 2018;19:28-40. doi: 10.1111/obr.12621

38. De Bacquer D, Van Risseghem M, Clays E, Kittel F, De Backer G, Braeckman L. Rotating shift work and the metabolic syndrome: a prospective study. Int J Epidemiol 2009;38:848-54. doi: 10.1093/ije/dyn360

39. Peplonska B, Bukowska A, Sobala W. Association of rotating night shift work with BMI and abdominal obesity among nurses and midwives. PLoS One 2015;10(7):e0133761. doi: 10.1371/journal.pone.0133761

\section{Povezanost smjenskog rada s pretilosti na velikom uzorku iranskih radnika u industriji čelika}

Pretilost je povezana s nekoliko kroničnih bolesti, a premda rezultati postojećih istraživanja upućuju na to da smjenski rad donosi rizik od prekomjerne tjelesne težine i pretilosti, oni su zasad kontroverzni. Osim toga, tek je nekolicina istraživanja objavila rezultate za industrijske radnike pod visokim stresom povezanim s poslom. Cilj je ovoga presječnog istraživanja bio utvrditi postoji li takva povezanost između smjenskoga rada i prekomjerne težine odnosno pretilosti na velikom uzorku od 3063 industrijska radnika iz zemlje u razvoju. Uzorak je dobiven među 16.000 radnika čelične industrije klasterskim uzorkovanjem u više faza. Prikupljeni su antropometrijski podaci o radnicima, uključujući indeks tjelesne mase (eng. BMI), opseg struka i omjer struka i bokova. Podaci o mogućim varijablama posredne povezanosti (engl. confounding variables) prikupljeni su upitnikom koji su ispunili ispitanici. Za utvrđivanje povezanosti smjenskoga rada s općom i trbušnom pretilosti rabljena je multinomijalna i binarna logistička regresijska analiza. Uzorak je obuhvatio 1683 radnika $(54,9 \%)$ u rotacijskim smjenama te 1380 radnika $(45,1 \%)$ u dnevnoj smjeni. Nakon prilagodbe prema varijablama posredne povezanosti utvrđeno je da je smjenski je rad značajno povezan s višim rizikom od prekomjerne tjelesne težine (OR=1,2; 95 \% CI:1,04-1,4), ali ne i s trbušnom pretilosti. Rezultati istraživanja ističu smjenski rad kao nezavisni čimbenik za prekomjernu tjelesnu težinu u industrijskih smjenskih radnika. U praktičnom smislu to znači da bi za smanjenje toga rizika trebalo promijeniti raspored smjena, osobito ako rad u smjenama traje dugo tj. ne izmjenjuje se s radom u isključivo dnevnoj smjeni.

KLJUČNE RIJEČI: BMI; omjer struka i bokova; opća pretilost; opseg struka; trbušna pretilost 